\title{
New approach for local C-band weather radar precipitation calibration
}

\author{
José Roberto ÁVILA-CARRASCO ${ }^{1}$, Graciela S. HERRERA ${ }^{1 *}$, \\ Hugo Enrique JÚNEZ-FERREIRA ${ }^{2}$ and Arturo VALDÉS-MANZANILLA ${ }^{3}$
}

${ }^{1}$ Departamento de Recursos Naturales, Instituto de Geofísica, Universidad Nacional Autónoma de México, Circuito de la Investigación Cientifica s/n, Ciudad Universitaria, 04150 Ciudad de México, México.

${ }^{2}$ Doctorado en Ciencias de la Ingeniería, Universidad Autónoma de Zacatecas, km 6 carretera Zacatecas-Guadalajara, Ejido la Escondida, 98160 Zacatecas, Zacatecas, México.

${ }^{3}$ División Académica de Ciencias Biológicas, Universidad Juárez Autónoma de Tabasco, km 0.5 carretera VillahermosaCárdenas, entronque a Bosques de Saloya, 86150 Villahermosa, Tabasco, México.

*Corresponding author; email: ghz@igeofisica.unam.mx

Received: August 30, 2019; accepted: March 3, 2020

\begin{abstract}
RESUMEN
La calibración de radares meteorológicos es un tema de gran interés actual, ya que es útil para diversas aplicaciones hidrológicas. No obstante, se han desarrollado varios métodos para ajustar la relación entre los datos de reflectividad $\mathrm{Z}$ y la intensidad de lluvia $\mathrm{R}(\mathrm{Z} / \mathrm{R})$. Esto se debe a que la distribución del tamaño de las gotas para diferentes tormentas es desconocida y muy variable en el tiempo y el espacio. El presente estudio desarrolló y probó un nuevo procedimiento basado en ventanas de tiempo y espacio para la calibración local óptima del radar meteorológico utilizando relaciones $\mathrm{Z} / \mathrm{R}$, y lo aplicó a tormentas convectivas y estratiformes en la cuenca baja del río Grijalva en México. Mejorar las estimaciones de lluvia del radar de Sabancuy, Campeche, es fundamental porque esta cuenca es propensa a inundaciones. Las estimaciones resultantes del procedimiento se basan en la optimización de ventanas $(\mathrm{OPV})$ usando la ley de potencia $\left(\mathrm{Z}=\mathrm{AR}^{\mathrm{b}}\right)$. Dichas estimaciones se comparan con las resultantes del uso de la relación predeterminada de Marshall y Palmer (MP) utilizando para ello los registros de pluviómetro observados. La ventana apropiada se seleccionó utilizando un criterio que considera los factores que afectan la caída libre de las gotas de lluvia. Para la mayoría de las tormentas probadas, los estadísticos de los modelos OPV mostraron mejores valores que los calculados para los modelos MP. El mejor rendimiento de MP ocurrió cuando se utilizaron datos de calibración suavizados, pero sólo se alcanzaron resultados similares a los obtenidos con OP. El método de calibración propuesto podría ser útil para mejorar las estimaciones del modelo MP por defecto en cualquier radar meteorológico con características similares a las analizadas en este trabajo. Las relaciones $\mathrm{Z} / \mathrm{R}$ resultantes podrían mejorar las estimaciones del radar de precipitación para la captura de datos en modelos hidrológicos.
\end{abstract}

\begin{abstract}
Weather radar calibration is a topic of great current interest because it is useful for various hydrological applications. Several methods have been developed for adjusting the relation between reflectivity data $\mathrm{Z}$ and rainfall intensity $\mathrm{R}(\mathrm{Z} / \mathrm{R})$ because droplet size distributions in different storm events are unknown and highly variable in time and space. The present study developed and tested a new space and time window-based procedure for optimal local calibration of weather radar using Z/R relations and applying it to convective and stratiform storms in the lower Grijalva river basin in Mexico. Improving rain estimates from the Sabancuy, Campeche radar is essential because it monitors this basin, which is prone to floods. The resulting estimates of the optimal power-law $\left(\mathrm{Z}=\mathrm{AR}^{\mathrm{b}}\right)$ window-based procedure $(\mathrm{OP})$ are compared with those of the default Marshall and Palmer (MP) relation using the observed rain gauge records. The appropriate window was selected using a criterion that considers factors affecting the free fall of raindrops. For most of the storms tested, metrics for the OP models showed better values than those calculated for the MP ones. The best MP
\end{abstract}


performance is when using smooth calibration data, achieving similar metric results to that of the OP. The proposed observed calibration method could be useful to improve the default MP model estimates at any weather radar with similar characteristics to the ones analyzed in this work. The resulting $\mathrm{Z} / \mathrm{R}$ relations could improve precipitation radar estimates for hydrologic model inputs.

Keywords: optimization, flood, power-law, Grijalva river, space-time windows.

\section{Introduction}

Analyzing rain gauge information collected within a given basin or region allows understanding the hydrological cycle dynamics, which has a great relevance in socioeconomic, agricultural, and environmental sectors, among others. Applications range from designing and planning construction projects to predicting extreme events such as droughts and floods (Boushaki et al., 2009). Thus, rainfall information can be considered a basic asset that, like insurance, must be acquired to protect against an uncertain future. Recent developments in computing and Geographic Information Systems (GIS) have allowed distributed hydrological models to increase their popularity among researchers and others interested in the subject, increasing the demand for spatially distributed data in grid format (Mantas et al., 2015). In general, rainfall data is gathered mainly through rain gauge networks, or remote sensing, such as meteorological radars and satellites. These data sources have advantages as well as disadvantages, and differences between them may cause certain grid products to be unsuitable for some applications (Li and Shao, 2010; Woldemeskel et al., 2013).

Rain gauge networks are considered the only source of direct physical measurements of liquid precipitation and, therefore, the most reliable source of information. However, monitoring sites are often scattered and poorly distributed, limited by the spatial coverage that prevents their use in hydrological applications. On the other hand, data produced by remote sensors (radar and satellite) represent a potential high-resolution alternative when rain gauge networks are dispersed, especially in poorly monitored regions. Nevertheless, satellite data are indirect measurements that have limitations due to spatio-temporal measurement scales, cloud effects, and the lack of effective algorithms for data recovery (Long et al., 2016).

Weather radar overcomes some rain gauge and satellite data limitations, as they provide high-resolution raster data with measurements closer to the Earth's surface than those of satellites. However, radar data require sophisticated post-processing to eliminate some errors such as beam attenuation, bright band effects (Rico-Ramírez et al., 2005), variation in the vertical profile of reflectivity (VPR) (Hill and Baron, 2015), reflectivity attenuation (Gou et al., 2019), non-meteorological echoes (Dufton and Collier, 2015), and anomalous propagation (Zhang et al., 2019).

Using radar information for environmental and hydrological applications is a topic of great current interest. Since droplet size distributions in different storm events are unknown and vary in time and space, the relationship between reflectivity data $\mathrm{Z}$ and rainfall intensity $R(Z / R)$ is not unique. There are several average empirical $\mathrm{Z} / \mathrm{R}$ relationships that radars use as default, and the most used expression is based on the empirical study of Marshall and Palmer (1948). However, several researchers and practitioners have developed methodologies that improve those default relationships between reflectivity data $\mathrm{Z}$ and rainfall intensity $\mathrm{R}$. The objective is to transform radar reflectivity $\left(\mathrm{mm}^{6} \mathrm{~m}^{-3}\right)$ into rainfall intensity $\left(\mathrm{mm} \mathrm{h}^{-1}\right)$, adjusting the parameters $\mathrm{A}$ and $\mathrm{b}$ in a power-law $\mathrm{Z} / \mathrm{R}$ relation $\left(\mathrm{Z}=\mathrm{AR}^{\mathrm{b}}\right)$. This process is commonly known as hydrological radar calibration.

Calheiros and Zawadzki (1987) applied a simple methodology, called the Traditional Matching Method (TMM), that determines the $\mathrm{Z} / \mathrm{R}$ relationship using regression analysis between two synchronous $\mathrm{R}$ and $\mathrm{Z}$ data sets in the pixel containing the calibration rain gauge. One disadvantage of this method is that perfect synchronization is only achievable in the ground at the closest distance. The same authors (Calheiros and Zawadzki, 1987) also applied the Probability Matching Method (PMM) to compensate for TMM's drawbacks. The PMM compares the non-synchronous $\mathrm{Z}$ and $\mathrm{R}$ pairs that have the same cumulative density function.

Window-based methods have proven to be effective, because they allow achieving an optimal Z/R 
relation by looking for the closest $\mathrm{R}$ to $\mathrm{Z}$ value within a mesh (window) of different spatial and temporal dimensions. Rosenfeld et al. (1994) developed the Window Probability Matching Method (WPMM) to overcome PMM weaknesses by matching $\mathrm{Z}$ and $\mathrm{R}$ pairs in small space-time windows to account for collocation and timing errors. The WPMM provided significantly better results when estimating rain intensity. An advantage of PMM and WPMM is that there are no concurrent requirements for the $\mathrm{Z}$ and $\mathrm{R}$ data sets. On the other hand, the disadvantages are that these techniques do not represent the actual physical rain process nor use a joint probability for $\mathrm{Z}$ and $\mathrm{R}$.

Piman et al. (2007) developed a window-based method, called Window Correlation Matching Method (WCMM), to account for collocation and timing errors. They compared the results with those of the TMM and the WPMM for different scenarios of space-time window sizes, getting the best results using a space window of $7 \times 7 \mathrm{~km}$ and a time lag of $-5 \mathrm{~min}$. The results of the WCMM improved those of the TMM and the PMM, which were overestimated and underestimated, respectively. Yet, for the case study, the WCMM produced a slightly higher rainfall estimation than other methods. However, these authors did not consider any specific criterion to select an appropriate window size.

The adjustment of the $\mathrm{Z} / \mathrm{R}$ relation has been addressed by Alfieri et al. (2010) in the northeast of Italy, readjusting the parameters of the power-law at each time step to find the optimal $\mathrm{Z} / \mathrm{R}$ relation. The analysis was done for distances less than $25 \mathrm{~km}$ from the radar site, comparing rainfall and radar data for 19 rain events. The adjusted Z/R relation produced a $28 \%$ reduction of the standard error using a time window of 2 to $5 \mathrm{~h}$ compared to the most accurate fixed $\mathrm{Z} / \mathrm{R}$ relation found in the literature. However, this method did not account for a calibration area away from the radar, nor space windows, only the temporal window.

Ramli and Tahir (2013) in Malaysia developed new $\mathrm{Z} / \mathrm{R}$ ratios for a Doppler radar using an optimal reflectivity and rain curve for different rainfall types based on their intensity, but this method did not include errors of location or timing. More recently, Ayat et al. (2018) developed the Region Probability Matching Method (RPMM) to calibrate the Amir-
Abad weather radar located in northern Iran. This method overcame the applicability limitations of previous methods in regions with scattered monitoring, light rains, and poor space-time resolutions. Using 6-h records from 18 synoptic stations and 15 min frequency radar data records, they compared $\mathrm{Z} / \mathrm{R}$ pairs over the entire radar domain and used the correlation coefficient of a linear model as the criterion to adjust the parameters $A$ and $b$. The results indicate that RPMM was better than TMM; however, this method did not use a power-law $\mathrm{Z} / \mathrm{R}$ relationship.

In the present study, a new algorithm for a window-based method to find the optimal $A$ and $b$ power-law parameters was developed to ensure the best $\mathrm{Z} / \mathrm{R}$ relationship. It was tested in the lower Grijalva river basin located between the Mexican states of Tabasco and Chiapas and compared with the performance of the Marshall and Palmer relation, which is the default method to calculate rainfall intensity in the study area. The region covered in this study is affected by extreme hydrometeorological events that put the population in constant risk (Pedrozo-Acuña et al., 2012), an ideally suited area to develop flood risk management strategies. The main objective of this work is to improve rainfall estimates from the radar installed in the town of Sabancuy, Campeche by finding appropriate local $\mathrm{Z} / \mathrm{R}$ relations that would increase the reliability of weather-radar rainfall estimations, making them suitable for the critical hydrological applications needed.

\section{Study area and data}

The Grijalva river originates in Guatemalan mountains and receives different names along its course. Traversing the Mexican states of Chiapas and Tabasco, it flows into the Gulf of Mexico. The Grijalva basin is one of the largest in Mexico, and it is divided into three sub-basins: upper, middle, and lower (Hinojosa-Corona et al., 2011). The latter, also called lower Grijalva river basin (LGRB), is within the Grijalva-Usumacinta hydrological region in southeastern Mexico, within the states of Chiapas and Tabasco (Fig. 1). The LGRB covers an area of $23544 \mathrm{~km}^{2}$ between the geographical coordinates $16^{\circ} 50^{\prime}-18^{\circ} 50^{\prime} \mathrm{N}$ and $91^{\circ} 40^{\prime}-93^{\circ} 40^{\prime} \mathrm{W}$, and its maximum elevation is 2892 masl. Elevations within the LGRB are lower than 0 masl, which corresponds 


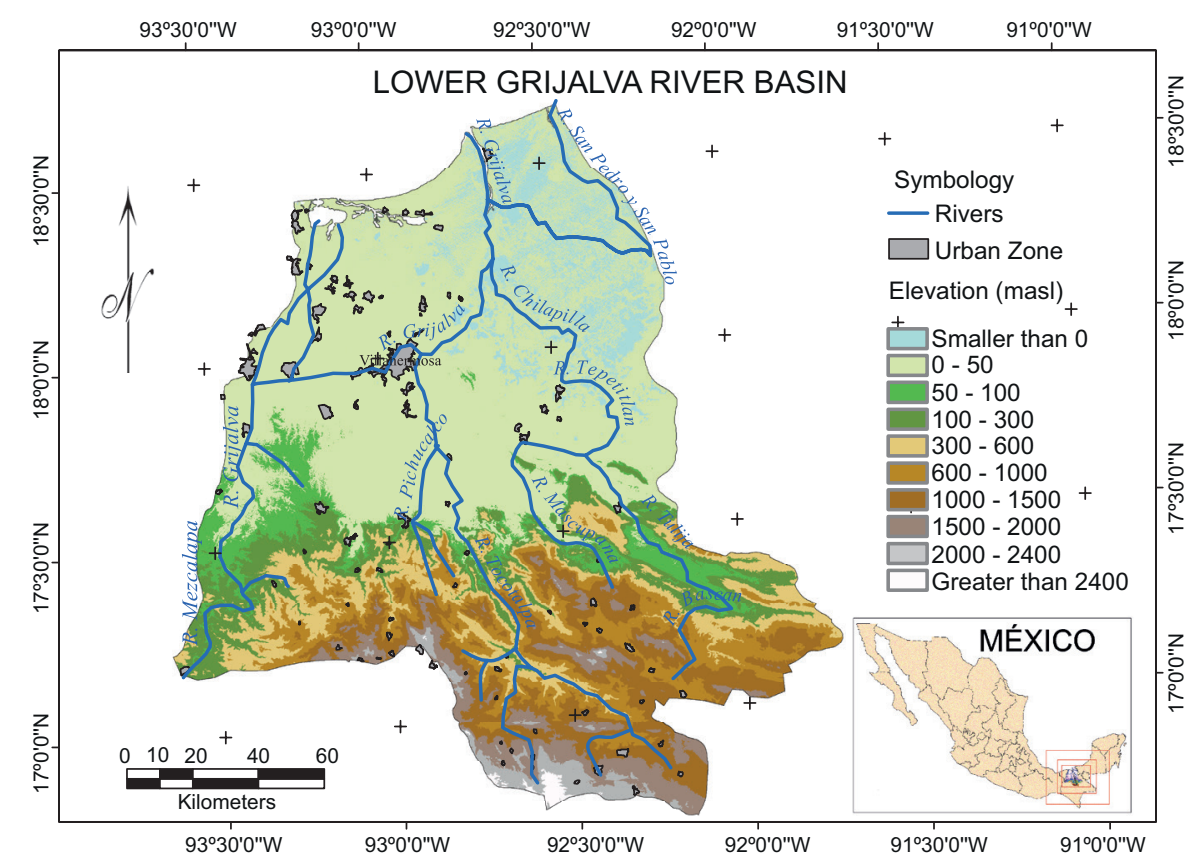

Fig. 1. Spatial location, hydrography, urban areas, and topography of the lower Grijalva river basin.

to extensive depressions that remain flooded with fresh water for most of the year (Zavala et al., 2016).

Based on its climate and terrain, the LGRB is subdivided into three regions: (1) highland zone, corresponding to the mountainous region of the basin with elevations ranging from 300 to 2892 masl; (2) transition zone, with elevations ranging from 100 to 300 masl, and (3) lowland zone, with elevations from -20 to 100 masl (Velasco-Martínez et al., 2011). Rainfall is distributed unevenly both in space and time within these three sub-regions, whose climate diversity is present mainly at the highland zone, while it is more homogeneous at the lowland. The maximum rainfall in the LGRB occurs during September, being the transition zone the wettest region with more than $500 \mathrm{~mm}$ of monthly rainfall, while in the highland and lowland areas it is around 369 and $360 \mathrm{~mm}$ during the same month, respectively. On the other hand, in this basin the most frequent annual rainfall ranges from 1801 to $2200 \mathrm{~mm}$ (Velasco-Martínez et al., 2011), which is a much larger value compared to the drier northern regions (13-430 $\mathrm{mm}$ ) or the Mexican national average $(700 \mathrm{~mm})$.

\subsection{Radar and rain gauge data}

The National Weather Service (SMN, by its Spanish acronym) of Mexico operates a network of 13 weather radars, most of them in southern Mexico. Two radars partially cover the LGRB, located in the towns of Sabancuy in Campeche and Mozotal in Chiapas. The latter is located at 2900 masl and only covers the upper part of the GLRB. The Sabancuy radar (Fig. 2), which covers all the physio-climatic regions of the basin, is located at $18^{\circ} 58^{\prime} 20.784^{\prime}$ ' $\mathrm{N}$ and $91^{\circ} 10^{\prime}$ 21.5904 " W at only 17 masl ( 5 m of land plus a 12 $\mathrm{m}$ tower). Installed in 2012, the Sabancuy radar is a dual-polarized Doppler type with a coaxial magnetron, operating in the type C-band (wavelength $\lambda=5 \mathrm{~cm}$ and frequency of 4-8 GHz). Dual polarization means better estimation and hydrometeor classification (like hail and rain) in quantitative rainfall calculation.

Dual polarization type C-band radars are preferable than single polarization type $\mathrm{S}$-band radars $(\lambda=10 \mathrm{~cm})$ because they are less expensive and bulky, they allow precise real-time correction of beam attenuation and they provide similar accuracy to single-polarization type S-band radars. Table I presents 
some technical characteristics of the Sabancuy radar and the Marshall and Palmer (1948) relation, which is used as a default for this radar by the SMN. PPI images from the Sabancuy radar $Z$ values were generated using volume data recorded every $15 \mathrm{~min}$, with a resolution of $1 \mathrm{~km}$ in the radial direction and $1^{\circ}$ in the azimuthal direction. The images were generated using measured reflectivity at a lower angle of $0.49^{\circ}$ of the antenna elevation, which was done by applying the $\mathrm{R}$ open source library radar.IRIS developed by Hill and Baron (2015).

Table I. Technical characteristics of the Sabancuy radar.

\begin{tabular}{lc}
\hline Type & Coaxial magnetron \\
\hline Model & Vaisala WRM200 \\
Beam width & $<1^{\circ}$ \\
Operating frequency range & $5.5-5.7 \mathrm{GHz}$ \\
Peak power & $250 \mathrm{~kW}$ \\
Average power & $\max 300 \mathrm{~W}$ \\
Antenna diameter & $4.5 \mathrm{~m}$ \\
Pulse amplitudes & $0.5,0.8,1.0,2.0 \mathrm{~ms}$ \\
PRF & 200 to $2400 \mathrm{~Hz}$ \\
Receiver noise & $<2 \mathrm{~dB}$ \\
Default Z/R model & $\mathrm{Z}=200 \mathrm{R}^{1.6}$ \\
\hline
\end{tabular}

There is a reasonably good rain-gauge $24-\mathrm{h}$ monitoring network at the LGRB, but only a few of the stations are automatic. Not all of them have data for the selected period and some data gaps are present, further reducing the number of available rain gauges. Figure 2 shows the stations that record near real-time data (every $10 \mathrm{~min}$ ), comprised of meteorological synoptic stations (ESIME, by its Spanish acronym) and automatic meteorological stations (EMA, by its Spanish acronym). Daily records and near-real-time data stations, as well as radar raw data, were provided by the SMN for a period that ranges from January 1 , 2016 to August 31, 2018. The rainfall information was provided in Microsoft Excel spreadsheets for 10 selected near-real-time data rain gauge stations (Table II) within the Sabancuy radar range (Fig. 2).

\section{Methodology}

The developed algorithm is based on space and time windows (Piman et al., 2007) and it reduces collocation and timing errors present when radar calibration is carried out using rain gauges. The method consists of comparing pairs of radar reflectivity and rain-gauge rainfall intensity values $(Z$ and $\mathrm{Rg}$, respectively). The window refers to a mesh of cells

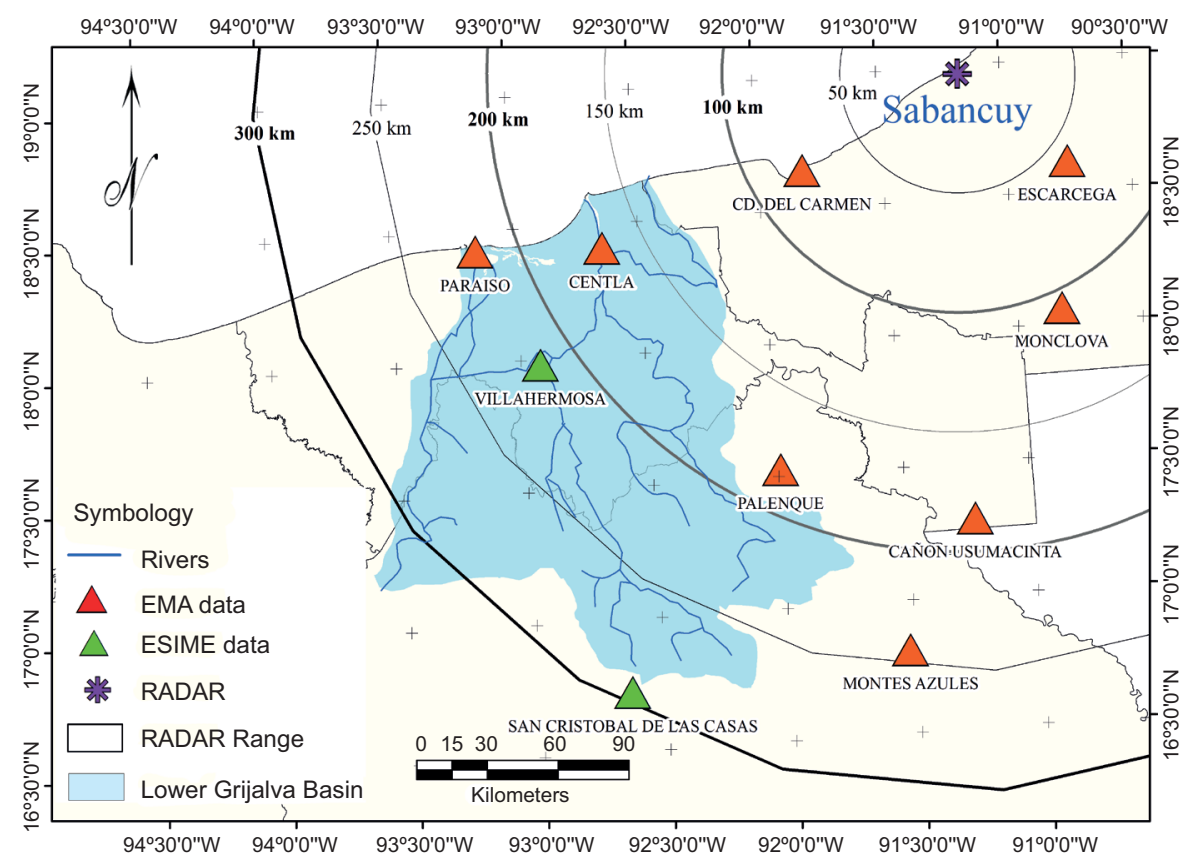

Fig. 2. Radar and automatic stations with influence in the lower Grijalva river basin. 
Table II. Weather stations used in this study within the Sabancuy radar range and beam height.

\begin{tabular}{llcccc}
\hline Rain gauge name & State & Latitude & Longitude & Beam height $(\mathrm{km})$ & Range $(\mathrm{km})$ \\
\hline San Cristóbal de las Casas & Chiapas & $16^{\circ} 45^{\prime} 36^{\prime \prime}$ & $92^{\circ} 37^{\prime} 48^{\prime \prime}$ & 7.6 & 294 \\
Villa Hermosa & Tabasco & $17^{\circ} 58^{\prime} 48^{\prime \prime}$ & $92^{\circ} 55^{\prime} 48^{\prime \prime}$ & 4.7 & 218 \\
Palenque & Chiapas & $17^{\circ} 30^{\prime} 00^{\prime \prime}$ & $91^{\circ} 54^{\prime} 00^{\prime \prime}$ & 3.6 & 184 \\
Centla & Tabasco & $18^{\circ} 24^{\prime} 00^{\prime \prime}$ & $92^{\circ} 37^{\prime} 48^{\prime \prime}$ & 3.1 & 167 \\
Paraíso & Tabasco & $18^{\circ} 25^{\prime} 23^{\prime \prime}$ & $93^{\circ} 09^{\prime} 20^{\prime \prime}$ & 4.9 & 223 \\
Cañón Usumacinta & Tabasco & $17^{\circ} 17^{\prime} 23^{\prime \prime}$ & $91^{\circ} 13^{\prime} 44^{\prime \prime}$ & 3.6 & 185 \\
Isla del Carmen & Campeche & $18^{\circ} 39^{\prime} 29^{\prime \prime}$ & $91^{\circ} 45^{\prime} 55^{\prime \prime}$ & 0.9 & 72 \\
Escárcega & Campeche & $18^{\circ} 39^{\prime} 29^{\prime \prime}$ & $91^{\circ} 45^{\prime} 55^{\prime \prime}$ & 0.7 & 60 \\
Monclova & Campeche & $18^{\circ} 39^{\prime} 29^{\prime \prime}$ & $90^{\circ} 49^{\prime} 15^{\prime \prime}$ & 1.5 & 102 \\
Montes Azules & Chiapas & $16^{\circ} 48^{\prime} 43^{\prime \prime}$ & $91^{\circ} 31^{\prime} 29^{\prime \prime}$ & 5.6 & 244 \\
\hline
\end{tabular}

that contains the reflectivity values from a radar raster image, where the central cell matches the spatial location of the calibration rain gauge. $\mathrm{Rg}$ point values are compared with $\mathrm{Z}$ values by forming pairs with Rz values calculated by means of a power regression equation $\left(Z=A R_{z}^{b}\right)$. Those $\mathrm{Z}$ values are measured at the calibration rain-gauge surrounding cells. The number of pairs depends on the size of the mesh (e.g., $5 \times 5 \mathrm{~km}^{2}$ ) (Fig. 3). The sought value of $\mathrm{Z}$ maximizes the coefficient of determination $\left(\mathrm{r}^{2}\right)$ obtained by adjusting the parameters A and b of the power model. This process is done over the present and previous times of the measurements (e.g., $0,-10$, or $-20 \mathrm{~min}$ )

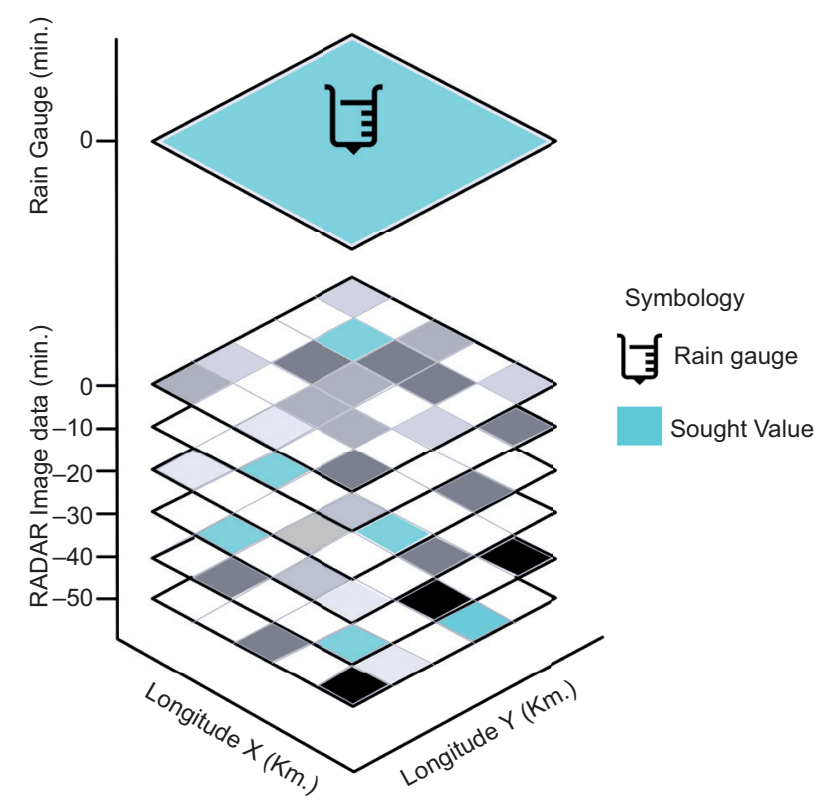

Fig. 3. Conceptualization of the space-time windows matching method. considering errors caused mainly by the height of the beam radar measurement, raindrop evaporation, and wind speed. The spatial and temporal window dimensions must be large enough for better results.

The optimization algorithm was programmed in $\mathrm{R}$ language (Venables et al., 2019) and is applied recursively at every state of the power-law parameters $\mathrm{A}$ and $\mathrm{b}$ to find the optimum. It is a search algorithm that consists of selecting the best solution and making it the current solution. In other words, it is applied consecutively for each parameter $\mathrm{A}$ and $\mathrm{b}$, taking as an objective function the maximization of the corresponding coefficient of determination $\left(\mathrm{r}^{2} \mathrm{Aj}\right.$ and $\mathrm{r}^{2}{ }_{\mathrm{bj}}$, respectively) that results from adjusting the power model for each parameter. Note that both parameters correspond to the same equation but are optimized separately but simultaneously optimized at each optimization iteration until the convergence of their respective $r^{2}$. The coefficient of determination, also called multiple correlation coefficient, is defined as the proportion of variation explained by the regression model (Nagelkerke, 1991). The optimum state is reached when a convergence criterion is accomplished $\left(r^{2}{ }_{A j}=r^{2}{ }_{b j}\right)$. The optimization algorithm scheme of parameters $\mathrm{A}$ and $\mathrm{b}$ for the power-law is presented in Figure 4, where the specific steps to follow are:

1. Define non-zero $Z$ and $\mathrm{Rg}$ pairs according to a selected space-time window.

2. Propose initial $\mathrm{j}_{0}$ state values of $\mathrm{A}$ and $\mathrm{b}\left(\mathrm{A}_{0}\right.$ and $\left.\mathrm{b}_{0}\right)$.

3. Generate a list of iteration values $\left(\mathrm{A}_{\mathrm{i}}\right.$ and $\left.\mathrm{b}_{\mathrm{i}}\right)$, where $i$ takes values between a range defined by the user (dependent of event type characteristics). 


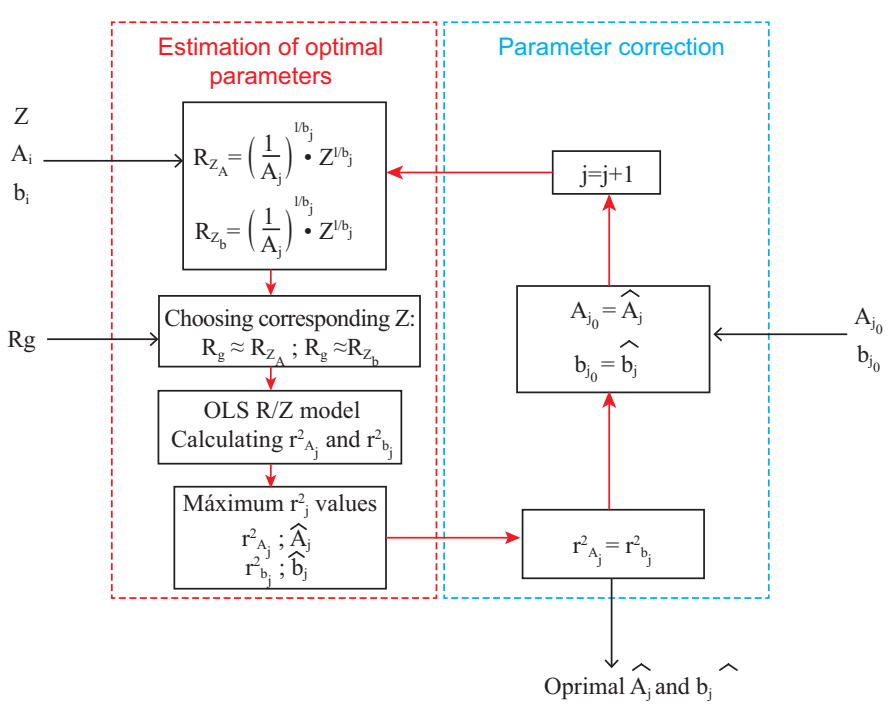

Fig. 4. Optimization process for the $\mathrm{A}$ and $\mathrm{b}$ parameters.

4. Calculate $R_{Z}$ for each cell window using the corresponding $Z$ values and the list of $A_{i}$ or $b_{i}$ values.

5. Select the cell that contains the $R_{Z}$ value that is the closest to the $\mathrm{Rg}$ value.

6. Conform a new set of $Z$ and $R$ pairs, now using the corresponding $\mathrm{R}_{\mathrm{Z}}$ and $\mathrm{Rg}$ closest values.

7. Adjust the power model (linearizing with the $\log _{10}$ transformation) and choose the parameters $\mathrm{Ai}_{\text {opt }}$ or bi $\mathrm{i}_{\text {opt }}$ that maximize $\mathrm{r}_{\mathrm{Aj}}$ and $\mathrm{r}_{\mathrm{bj}}^{2}$, respectively, at each state $\left(\mathrm{j}_{0}=0, \mathrm{j}_{1}=1, \mathrm{j}_{2}=2, \ldots, \mathrm{j}_{\mathrm{n}}=\right.$ n) iteration.

8. After applying steps 4 to 7 for the initial values $\left(A_{0}\right.$ and $\left.b_{0}\right)$ the first state is completed $\left(j_{0}\right)$. For subsequent $\mathrm{j}$-states the initial $\mathrm{A}_{0}$ and $\mathrm{b}_{0}$ are replaced by the state optimal values ( and ). The final optimal $A$ and $b$ values are obtained when $r^{2}{ }_{A j}$ and $r^{2}{ }_{b j}$ converge, otherwise steps 4 to 7 are repeated for consecutive states.

\subsection{Performance metrics}

The performance metrics (error measures) used to examine the resulting $\mathrm{Z} / \mathrm{R}$ relations include the root mean square error (RMSE, $\mathrm{mm}$ ) and its ratio with the observed rainfall root mean square standard deviation ratio (RSR) (Moriasi et al., 2007). RMSE values close to zero indicate a good fit between the rain gauge and radar data. RMSE penalizes large errors and it is more appropriate when the errors have a normal distribution (Chai and Draxler, 2014), while RSR is a standardized alternative that shows the degree of variation of the sample. A low RSR in combination with a small RMSE indicates a good correspondence between the two data sets (Singh et al., 2005). Other common metric for evaluating the difference (or error $\mathrm{e}_{\mathrm{i}}$ ) between observed and estimated values is the mean error (ME, mm), which indicates the level of overestimation or underestimation of measured values; its optimum value is zero. The corresponding equations are as follows:

$M E=\frac{\sum_{i=1}^{n} e_{i}}{n}$

$R M S E=\sqrt{\frac{\sum_{i=1}^{n}\left(e_{i}\right)^{2}}{n}}$

$\mathrm{RSR}=\sqrt{\frac{\sum_{i=1}^{n}\left(e_{i}\right)^{2}}{\sum_{i=1}^{n}\left(R g_{i}-\overline{\mathrm{Rg}}\right)^{2}}}$

where $\overline{R g}$ is the mean of the rain-gauge rainfall intensity observations.

The percentage difference in cumulative average precipitation (PDCA) is also calculated. Negative (positive) PDCA values indicate underestimation (overestimation) of the accumulated rain gauge data. It is calculated using the following equation:

$P D C A=\frac{(A R z-A R g)}{A R g} \times 100$ 
where $A R_{\alpha}, \alpha=z$ or $g$, is the cumulative precipitation of the corresponding data source. The relation between radar and rain gauge data is not linear, and in general the power-law of the form $\mathrm{Z}=\mathrm{AR}^{\mathrm{b}}$ gives the best fit of the data (Brase and Brase, 2009). Thus, to find the correlation between these two types of data, a power-type mathematical regression model should be adjusted (Newman, 2005). The power-law equation is linearized applying a logarithmic transformation: $\log \mathrm{Z}=\log \mathrm{A}+\mathrm{b} \log \mathrm{R}$.

It is possible to calculate the correlation expressed as the coefficient of determination $\left(\mathrm{r}^{2}\right)$ from the adjusted least-squares line. The correlation varies from 0 to 1 and indicates the model goodness of fit. It defines the proportion of the variance of the measured rainfall that is explained by the regression model. Values of $\mathrm{r}^{2}>$ 0.5 are considered acceptable, while $r^{2}=1$ indicates a perfect correlation, but $\mathrm{r}^{2}=0$ reveals that the mean is a better predictor than the model, which is unacceptable. The equation for $r^{2}$ between the radar rain estimates $(\mathrm{E})$ and the rain gauge observed values $(\mathrm{O})$ is given by the following equation:

$r^{2}=\frac{\left(n \sum O_{i} E_{i}-\sum O_{i} \sum E_{i}\right)^{2}}{\left[\left(n \sum O_{i}^{2}-\left(\sum O_{i}\right)^{2}\right]\left[\left(n \sum E_{i}^{2}-\left(\sum E_{i}\right)^{2}\right]\right.\right.}$

It is also important to apply criteria to reasonably determine window dimensions of space and time. Calheiros and Zawadzki (1987) proposed a relationship to compare different spatiotemporal distributions of these two types of data sources, assuming that the temporal resolution of rainfall data should be equivalent to the spatial resolution of radar data. Taking into account rainfall statistical properties this relationship is given by the following equation:
$1.3 \sqrt{A r}=v t \rightarrow A r=\left(\frac{t v}{1.3}\right)$

where $A r$ is the area of the radar data, $t$ is the temporal resolution of rain gauge data, and $v$ is the translation speed of the precipitation cells. An alternative is to use the kinematic equation of semi-parabolic motion to find the distance at which a raindrop is advected by the wind. This expression is $x=v t$, so the distance $(x$ in meters) is equal to the product of the wind speed ( $v$ in $\mathrm{ms}^{-1}$ ) in the time ( $t$ in seconds) that the falling raindrop takes to reach the ground.

\section{Results and discussion}

The methodology was tested in a total of seven storms, covering both stratiform and convective cases that occurred in winter and summer (Table III). In general, the stratiform-type storms have more compact spatial and temporal distributions compared with convective ones. Radar calibration for each of the storm events is performed by means of near real-time stations with data records taken every 10 min. Rainfall data values occur uneven at each position so that the number of $\mathrm{Z} / \mathrm{R}$ pairs at each recording time was variable. Note also that null records were removed, further reducing the number of $\mathrm{Z} / \mathrm{R}$ pairs. Rain gauge stations installed on the towns of Villahermosa, Centla, Isla del Carmen, Paraíso, and Escárcega had a larger number of data for the period of interest. To compare both data sources at the same frequency with the largest number of pairs possible, the Sabancuy radar records were interpolated to a 10 min frequency using the two adjacent temporal measurements.

Table III. Storm events analyzed.

\begin{tabular}{lcccccc}
\hline Date & $\begin{array}{c}\text { Start } \\
(\mathrm{LT})\end{array}$ & $\begin{array}{c}\text { End } \\
(\mathrm{LT})\end{array}$ & $\begin{array}{c}\text { Duration } \\
(\mathrm{h})\end{array}$ & $\begin{array}{c}\text { Precipitation } \\
(\mathrm{mm})^{*}\end{array}$ & $\begin{array}{c}\text { Mean intensity } \\
(\mathrm{mm} / \mathrm{h})\end{array}$ & $\begin{array}{c}\text { Storm event } \\
\text { type }\end{array}$ \\
\hline $01 / 02 / 2016$ & $9: 30$ & $23: 00$ & $13: 30$ & 86.00 & 6.37 & Stratiform \\
$20 / 07 / 2016$ & $3: 00$ & $9: 30$ & $6: 30$ & 39 & 6.15 & Convective \\
$16 / 02 / 2017$ & $8: 30$ & $12: 00$ & $3: 30$ & 21.00 & 6.00 & Stratiform \\
$29 / 01 / 2017$ & $11: 00$ & $18: 30$ & $7: 30$ & 25.6 & 3.41 & Stratiform \\
$13 / 02 / 2018$ & $5: 00$ & $7: 45$ & $2: 45$ & 28.00 & 10.18 & Convective \\
$14 / 02 / 2018$ & $2: 00$ & $5: 15$ & $3: 15$ & 68.25 & 21.00 & Convective \\
$04 / 06 / 2018$ & $20: 45$ & $0: 00$ & $3: 15$ & 48.40 & 14.89 & Convective \\
\hline
\end{tabular}

*Maximum accumulated rainfall recorded in one specific rain gauge. 
Table IV. Optimal parameter model results of the 29/01/2017 stratiform storm event.

\begin{tabular}{|c|c|c|c|c|c|c|c|c|c|c|c|c|c|c|c|}
\hline \multirow{3}{*}{$\begin{array}{c}\text { Spatial } \\
\text { window } \\
\left(\mathrm{km}^{2}\right)\end{array}$} & \multicolumn{15}{|c|}{ Temporal window (min) } \\
\hline & \multicolumn{3}{|c|}{0} & \multicolumn{3}{|c|}{-10} & \multicolumn{3}{|c|}{-20} & \multicolumn{3}{|c|}{-30} & \multicolumn{3}{|c|}{-40} \\
\hline & A & $\mathrm{b}$ & $r^{2}$ & $\mathrm{~A}$ & $\mathrm{~b}$ & $\mathrm{r}^{2}$ & A & $\mathrm{b}$ & $r^{2}$ & A & $\mathrm{b}$ & $r^{2}$ & A & $\mathrm{b}$ & $r^{2}$ \\
\hline $3 \times 3$ & 10.6 & 1 & 0.34 & 6.0 & 2.4 & 0.37 & 2.0 & 2.9 & 0.22 & 1.0 & 3.9 & 0.23 & 1 & 3.5 & 0.11 \\
\hline $5 \times 5$ & 6.7 & 1.74 & 0.53 & 11.0 & 1.7 & 0.62 & 6.0 & 1.8 & 0.37 & 2.0 & 2.9 & 0.25 & 1 & 3.6 & 0.21 \\
\hline $7 \times 7$ & 11.9 & 1.39 & 0.71 & 11.0 & 1.6 & 0.8 & 12.0 & 1.4 & 0.6 & 3.0 & 2.7 & 0.4 & 2 & 2.8 & 0.38 \\
\hline $9 \times 9$ & 19.3 & 1 & 0.85 & 17.8 & 1.1 & 0.9 & 14.1 & 1.2 & 0.76 & 19.0 & 1.3 & 0.55 & 19 & 1.6 & 0.58 \\
\hline $15 \times 15$ & 22 & 1 & 0.95 & 11.0 & 1.1 & 0.96 & 8.0 & 1.3 & 0.96 & 13.0 & 0.9 & 0.93 & 20 & 0.7 & 0.9 \\
\hline $17 \times 17$ & 31 & 0.5 & 0.97 & 17.0 & 0.8 & 0.97 & 6.0 & 1.3 & 0.96 & 14.0 & 0.6 & 0.98 & 25 & 0.6 & 0.96 \\
\hline $19 \times 19$ & 35 & 0.4 & 0.99 & 14.0 & 0.8 & 0.98 & 13.0 & 0.7 & 0.99 & 14.0 & 0.4 & 0.99 & 29 & 0.4 & 0.99 \\
\hline
\end{tabular}

For stratiform events, the iteration values were selected within the 0-100 range with increments of 1 for parameter $A$, while for parameter $b$ they were selected within the 0-5 range with increments of 0.1 . For convective events, to get an appropriate curve shape, the iteration ranges were twice as large as for the stratiform case ( 0 to 200 for A and 0 to 10 for $b$ ) with the same increments as before for both parameters. The lists of iteration values are used initially in the optimization process, then the increments are reduced, and in consequence, the number of iteration values increased.

Table IV shows the resulting $\mathrm{r}^{2}\left(=\mathrm{r}_{\mathrm{A}}^{2}=\mathrm{r}_{\mathrm{b}}^{2}\right)$ values and parameters $A$ and $b$, for the stratiform event observed on 29/01/2017, for each spatiotemporal window tested. The corresponding results for the convective event observed on 20/07/2016 is shown in Table V. For the stratiform event (Table IV), an $\mathrm{r}^{2}$ $=0.34$ can be observed for the $3 \times 3 \mathrm{~km}^{2}$ window time (0 $\mathrm{min})$.
Better values for $\mathrm{r}^{2}$ resulted at $-10 \mathrm{~min}$, which is evident from the $3 \times 3$ to $9 \times 9 \mathrm{~km}^{2}$, where an $\mathrm{r}^{2}$ of 0.9 was reached. Beyond $-10 \mathrm{~min}$, improvements are observed at -20 min with $\mathrm{r}^{2}=0.96$ for the 15 $\times 15 \mathrm{~km}^{2}$ window, and -30 min for the $17 \times 17 \mathrm{~km}$ window with $r^{2}=0.98$, which is almost a perfect correlation. Correlations above 0.9 are considered excellent. Similar results were obtained by Piman et al. (2007), who reported an increase in the correlation value for both the time and space-time scales. This is to be expected, since the more pixels are considered the higher the chances of finding values $\mathrm{Rz}$ closer to $\mathrm{Rg}$ values.

The performance of the optimization algorithm for the convective storm event was different, resulting in parameter values larger than those for the stratiform event. One possible reason is that summer rainstorms generally occur as showers, and differences among measurements at climate stations are larger (Ducrocq et al., 2002), hence they are more difficult to estimate

Table V. Optimal parameter model results of the 20/07/2016 convective storm event.

\begin{tabular}{|c|c|c|c|c|c|c|c|c|c|c|c|c|c|c|c|}
\hline \multirow{3}{*}{$\begin{array}{c}\text { Spatial } \\
\text { window } \\
\left(\mathrm{km}^{2}\right)\end{array}$} & \multicolumn{15}{|c|}{ Temporal window (min) } \\
\hline & \multicolumn{3}{|c|}{0} & \multicolumn{3}{|c|}{-10} & \multicolumn{3}{|c|}{-20} & \multicolumn{3}{|c|}{-30} & \multicolumn{3}{|c|}{-40} \\
\hline & $\mathrm{A}$ & $\mathrm{b}$ & $\mathrm{r}^{2}$ & $\mathrm{~A}$ & $\mathrm{~b}$ & $r^{2}$ & A & $\mathrm{b}$ & $\mathrm{r}^{2}$ & $\mathrm{~A}$ & $\mathrm{~b}$ & $\mathrm{r}^{2}$ & A & $\mathrm{b}$ & $\mathrm{r}^{2}$ \\
\hline $3 \times 3$ & 7 & 3.4 & 0.22 & 5 & 3.6 & 0.21 & 3 & 4.2 & 0.17 & 1 & 4.5 & 0.11 & 1 & 4.9 & 0.1 \\
\hline $5 \times 5$ & 24 & 2.8 & 0.27 & 12 & 3.4 & 0.39 & 6 & 3.8 & 0.3 & 3 & 4.2 & 0.21 & 3 & 4.1 & 0.2 \\
\hline $7 \times 7$ & 63 & 2.4 & 0.37 & 24 & 3.6 & 0.37 & 10 & 4.7 & 0.18 & 1 & 5 & 0.06 & 1 & 6.5 & 0.05 \\
\hline $9 \times 9$ & 36.3 & 2.56 & 0.43 & 30.2 & 2.71 & 0.63 & 19 & 3.1 & 0.48 & 8 & 3.5 & 0.38 & 7 & 3.4 & 0.34 \\
\hline $15 \times 15$ & 74 & 2 & 0.64 & 65 & 2.4 & 0.72 & 34 & 2.8 & 0.44 & 12 & 3.8 & 0.24 & 3 & 4.8 & 0.176 \\
\hline $17 \times 17$ & 68 & 1.9 & 0.82 & 55 & 2.2 & 0.84 & 25 & 2.7 & 0.7 & 15 & 2.9 & 0.58 & 9 & 3 & 0.52 \\
\hline $19 \times 19$ & 72 & 1.8 & 0.86 & 71 & 1.9 & 0.88 & 34 & 2.3 & 0.76 & 15 & 2.6 & 0.63 & 10 & 2.8 & 0.56 \\
\hline
\end{tabular}


using smaller windows (Junker et al., 2002). The $\mathrm{r}^{2}$ value improved when increasing the window size, but the number of stations used for calibration also had an impact.

This result is similar to that obtained by Hakvoort et al. (1993), who noted that increasing the number of rain gauges improved the model adjustment, but not as much as their placement; however, they did not differentiate between types of events. On the other hand, Lane et al. (1998) emphasized that a low-density rain gauge network (with separations of $5-20 \mathrm{~km}$ ) could be sufficient to obtain a good precipitation estimate for stratiform events because these could occur homogeneously in space and time. That is not the case for convective events, because temporal $\mathrm{Z}$ rate changes are larger and storm cores could be undetected between rain gauges. In the $-10 \mathrm{~min}$ temporal windows, an $\mathrm{r}^{2}$ improvement can be observed for all spatial windows except for $3 \times 3$ and $5 \times 5$ $\mathrm{km}^{2}$ (Table V). Note that an $\mathrm{r}^{2}$ of 0.9 is not obtained, suggesting that further window expansion is required.

Once $\mathrm{r}^{2}$ values for each spatial and temporal window were obtained, the question is which of these should be chosen to get the final estimates. The adequate window size was chosen using physical laws that answer the following question: Which is the maximum distance raindrops would be advected by the wind dragged a certain time period? Two alternatives were considered: (1) to apply the kinematic equation, and (2) to apply the equation proposed by Calheiros and Zawadzki (1987). The time $t$ that a raindrop takes to reach the ground was defined as 10 min, given the good $r^{2}$ results obtained for this time-window, and a mean speed $v$ of $25 \mathrm{~km} \mathrm{~h}^{-1}$ $\left(\sim 7 \mathrm{~m} \mathrm{~s}^{-1}\right)$, calculated from the analyzed storms, was chosen. The kinematic equation, disregarding the weight of the drops, results in:

$$
\text { Distance }=\left(7 \mathrm{~m} \mathrm{~s}^{-1}\right)(600 \mathrm{~s})=4.2 \mathrm{~km}
$$

corresponding to a radius in which the raindrops could fall and suggesting the selection of a $9 \times 9 \mathrm{~km}^{2}$ space and a $-10 \mathrm{~min}$ window, respectively.

Equation 9 shows the results using Calheiros and Zawadzki (1987) method:

Area $=\frac{0.166 \mathrm{~h} \times 25 \mathrm{~km} \mathrm{~h}^{-1}}{1.3}=10.97 \mathrm{~km}^{2}$
The result suggests using a window between $3 \times 3$ and $4 \times 4 \mathrm{~km}^{2}$. Care should be taken in selecting the wind speed, since for very strong storms this value would be much larger. For example, for tropical storms it would exceed $90 \mathrm{~km} \mathrm{~h}^{-1}$, and for hurricanes it would range between 120 to $300 \mathrm{~km} \mathrm{~h}^{-1}$. The elevation error related to the Earth curvature should be considered as well, because for a distance of $200 \mathrm{~km}$ and an angle of $0.5^{\circ}$ it will be $4 \mathrm{~km}$ (Gao et al., 2006).

Figure 5a-d show the results for the $9 \times 9 \mathrm{~km}^{2}$ space and the present time (zero) window ( $a$ and $b$ for the stratiform storm, and $\mathrm{c}$ and $\mathrm{d}$ for the convective storm). The graphs show the maximum $\mathrm{r}^{2}$ curves for each $A$ and $b$ iteration value obtained with the optimization algorithm. The curves corresponding to the convective event have a less pronounced downward slope and the optimal values are reached later than for the stratiform event. The differences in the magnitude of the resulting $A$ and $b$ optimal parameters suggest their scale dependency. Similar results were found by Morin et al. (2003), who demonstrated that the increase in space and time scales for convective storms leads to an increase in the $\mathrm{A}$ and a reduction in the $b$ parameters.

In order to assess the benefit of the proposed optimization method, radar estimates were performed using both the A and b optimized parameters (OP) and the default Marshall and Palmer (MP) parameters; then, both were compared. Figure 6a, c shows the comparison of both estimates with $\mathrm{Rg}$ data. Note that the MP model is unable to match the peak values. Conversely, estimates in Fig. 6c show better correspondence with $\mathrm{Rg}$, which may be due to homogeneity in the rainfall space distribution, with the exception of a few peaks at the end of the graph. Figure $6 \mathrm{~b}, \mathrm{~d}$ shows the cumulative mean areal rainfall estimated by an increasing number of measured rain gauge values and the corresponding radar-estimated rainfall (when selecting only non-zero pairs) for both $\mathrm{OP}$ and MP, ordered by rain gauge station. Figure $6 \mathrm{~b}$ shows some divergence at the curve center caused by high values that correspond to the Escárcega rain gauge station.

Similar results were found by Craciun and Catrina (2016), who attributed differences at closer distances to the divergent distance of radar beam and gauges for a $0.5^{\circ}$ elevatio, and the altitude of the lifting condensation level (which is below the radar beam at 

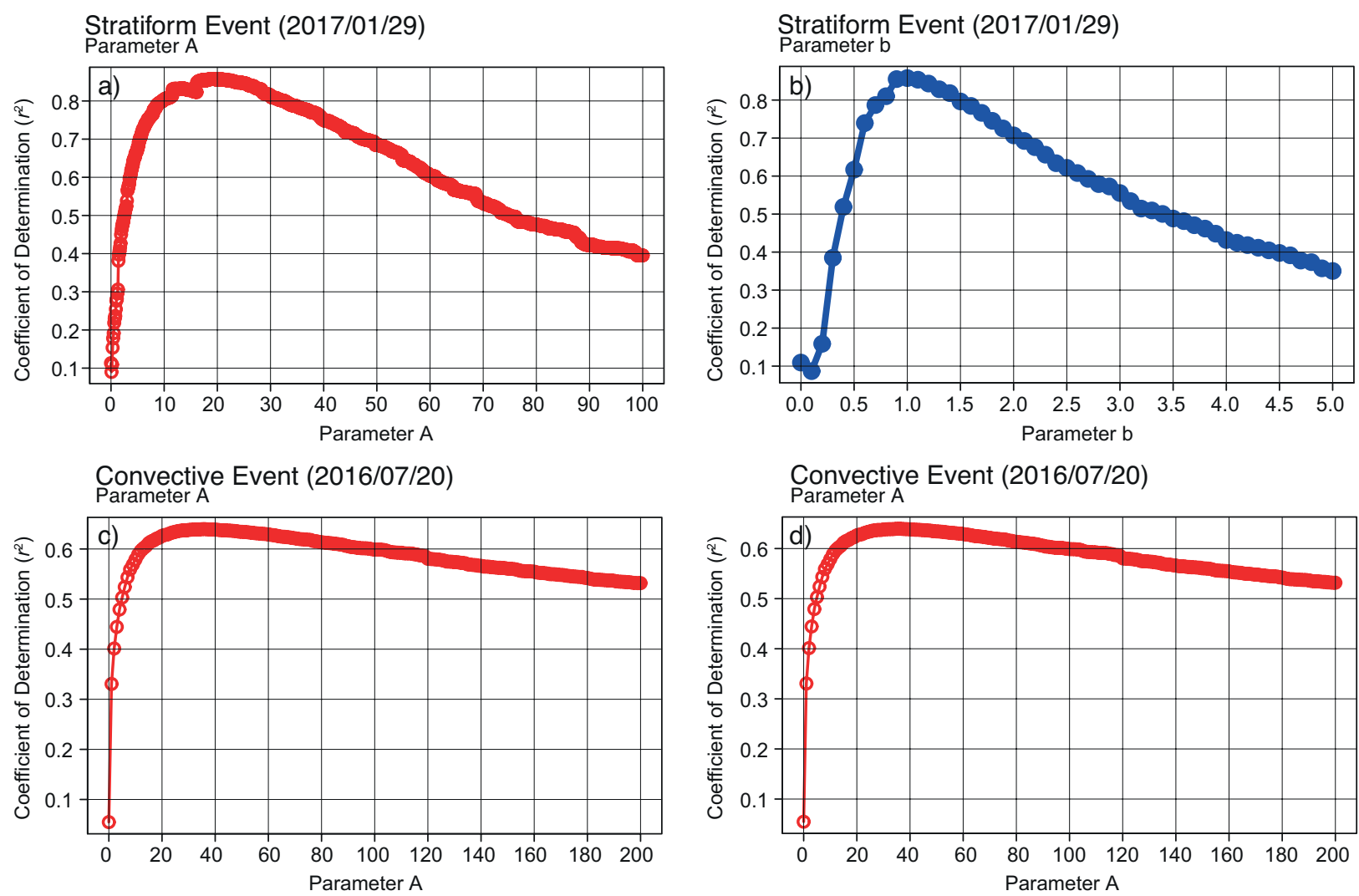

Fig. 5. Parameters A and b vs. $r^{2}$ curves for $(a, b)$ stratiform and $(c, d)$ convective storm events. The maximum value in each curve corresponds to the optimal parameters: $A=19.3, b=1$ for the stratiform event, and $A=36.3, b=2.56$ for the convective event.

long distances but higher at closer distances. Another possible reason for this radar overestimation is the remnant ground clutter echoes, and systematic and collecting data errors present at the rain gauge station are not ruled out. There is also a slight overestimation at the end of the curve at data pairs corresponding to the Villahermosa rain gauge station. Because this is the most distant station from the Sabancuy radar, errors are likely related to radar beam elevation, raindrop evaporation, signal attenuation, and systematic radar errors. The accumulated curve plot for the convective event (Fig. 6d) also shows a divergence in the center, but this is not very pronounced. The maximum separation occurs at the end of the curve due to the occurring peak values in this part.

The corresponding PDCA values (Table VI) were -21 and $10 \%$ using the OP model for convective and stratiform events, respectively. The negative PDCA value for the convective event means that rain gauge values were mainly overestimated by the OP model; the opposite occurs for the stratiform events. The resultant PDCA for the MP model shows that values are underestimated for both events with -18.7 and $-68.3 \%$, respectively. The percentages obtained using the OP model in both storm events are considered acceptable given the recorded rainfall magnitudes, but the resulting PDCA using the MP model for the convective is also high.

Scattergrams in Figure 7a, b show the estimated radar rainfall data vs. calibration rain-gauge values (in millimeters). Although the optimization algorithm computes $r^{2}$ using the power-law linearized equation, the purpose of these graphs is to compare rain gauge observed values with those estimated by the radar data. The scattergrams show that the power model gave better $r^{2}$ values than the linear model, yet the $\mathrm{r}^{2}$ difference between both models was small (not shown). Figure $7 \mathrm{~b}$ shows greater dispersion and a 

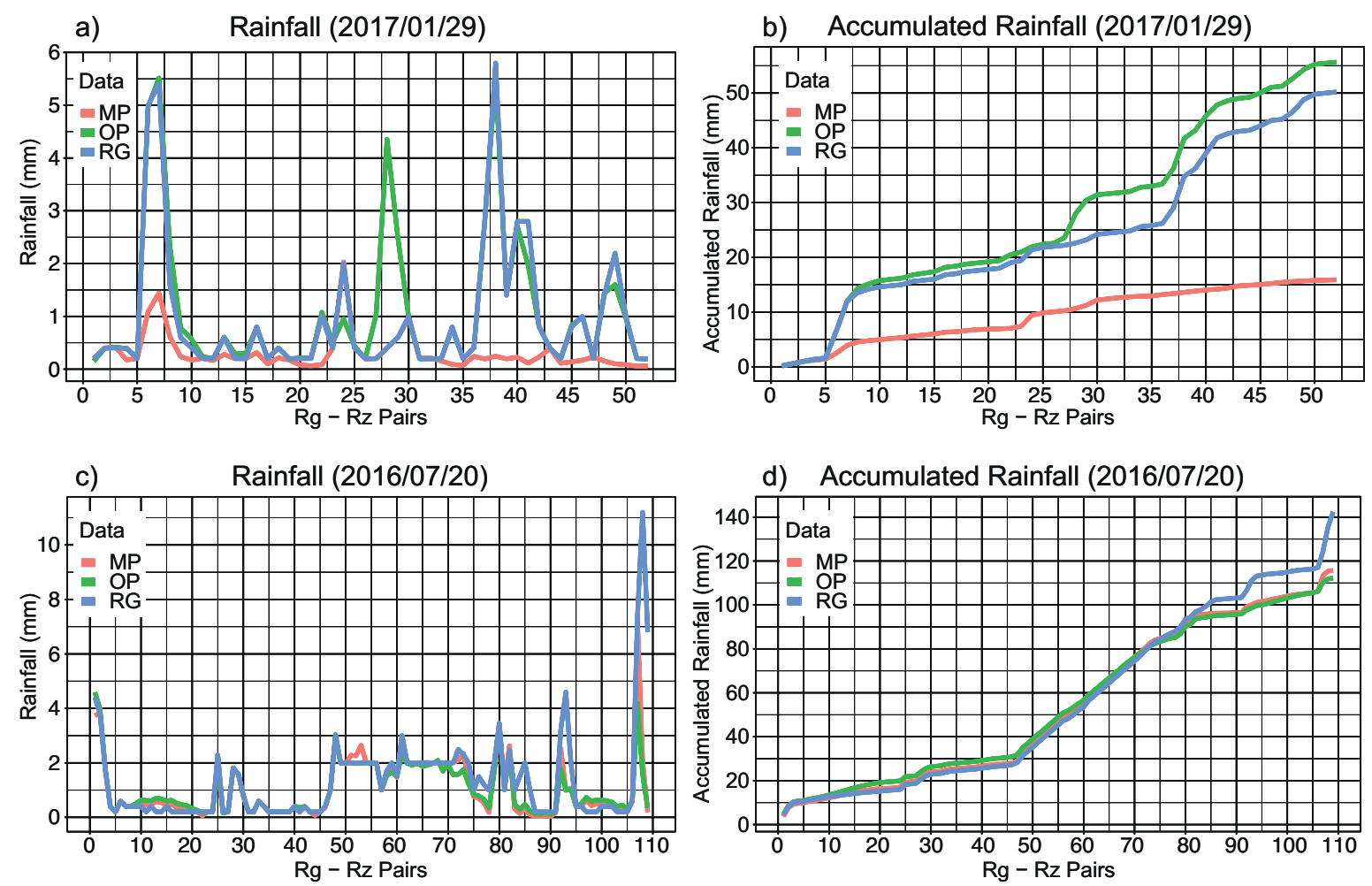

Fig. 6. Comparison by number of pairs of observed $(\mathrm{Rg})$ values and estimated values using optimized $\mathrm{A}$ and b parameters (OP) and the Marshall and Palmer default parameters (MP). (a) Value by value series of Rg vs. OP and MP for the 2017/01/29 event; (b) acummulated rainfall curve of Rg vs. OP and MP for the 2017/01/29 event; (c) value by value series of Rg vs. OP and MP for the 2016/07/20 event; (d) acummulated rainfall curve of Rg vs. OP and MP for the 2016/07/20 event.

smaller $r^{2}$ values than Figure $7 \mathrm{a}(0.69<0.86)$, which indicates that the convective storm has a higher complexity than the stratiform one. Nevertheless, the convective storm accumulated curve seems to fit data better than the stratiform curve. One reason may be the scale differences of each event, since the total accumulated rain for the stratiform event does not exceed $50 \mathrm{~mm}$, while in the convective event it was more than $140 \mathrm{~mm}$. Additionally, there are more $\mathrm{Z} / \mathrm{R}$ pairs with differences in the convective event, which result in a greater PDCA value.

The level of agreement for the rest of the storm events can be assessed using the Taylor diagram for the windows $3 \times 3$ to $15 \times 15 \mathrm{~km}^{2}$ at time zero (Fig. 8 ). The azimuth shows the correlation (r) between each tested window models and the observed data, while the radial distance measures the standard deviation (SD). The black hollow circle indicates correlation and standard deviation of the observed rain gauge data, and the other symbols indicate the tested window models. The closest the symbols are to the black hollow dot, the better the correspondence between the different window models with the rain gauge data.

The diagrams clearly show the advantage of using the optimized A and b parameters (filled symbols), instead of the default Marshall and Palmer parameters (hollow symbols). In almost all cases the filled symbols perform better than their hollow counterparts; this is more evident for the 2016/02/01, 2017/01/29, and 2018/02/13-14 storm events. For the 2017/02/16 and 2018/06/04 events, results for both the OP and MP approaches show good correlations $(>0.7)$ are observed in both events, especially in 2017/02/16. The 2016/07/20 storm event is the only one where MP results seems to be slightly better than those using OP parameters, but this difference is very subtle as can be seen in 
Table VI. Optimal parameters and performance metrics.

\begin{tabular}{|c|c|c|c|c|c|c|c|c|}
\hline Date & Window $(\mathrm{km})$ & A & b & RSR & RMSE (mm) & $\mathrm{ME}(\mathrm{mm})$ & $\mathrm{r}^{2}$ & PDCA (\%) \\
\hline \multirow{5}{*}{ 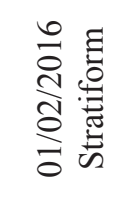 } & $3 \times 3$ & 3 & 2.3 & 0.70 & 0.99 & 2.78 & 0.50 & -33.50 \\
\hline & $5 \times 5$ & 4 & 1.8 & 0.43 & 0.61 & 1.22 & 0.81 & -10.38 \\
\hline & $7 \times 7$ & 4 & 1.7 & 0.36 & 0.52 & 1.42 & 0.86 & -6.37 \\
\hline & $9 \times 9$ & 7 & 1.2 & 0.34 & 0.48 & 1.53 & 0.83 & -3.09 \\
\hline & $15 \times 15$ & 8 & 0.8 & 0.36 & 0.52 & 2.97 & 0.86 & -0.83 \\
\hline \multirow{5}{*}{ 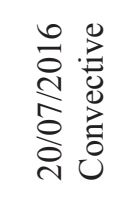 } & $3 \times 3$ & 7 & 3.4 & 0.88 & 1.42 & 2.39 & 0.22 & -28.72 \\
\hline & $5 \times 5$ & 24 & 2.8 & 0.86 & 3.85 & $1.2 \mathrm{E}-16$ & 0.27 & -28.87 \\
\hline & $7 \times 7$ & 63 & 2.4 & 0.79 & 1.28 & 2.40 & 0.37 & -28.03 \\
\hline & $9 \times 9$ & 36.3 & 2.56 & 0.75 & 1.22 & 5.91 & 0.43 & -21.18 \\
\hline & $15 \times 15$ & 74 & 2 & 0.60 & 0.97 & -8.18 & 0.64 & -14.76 \\
\hline \multirow{5}{*}{ 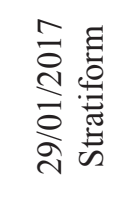 } & $3 \times 3$ & 10.6 & 1 & 0.97 & 1.27 & $4.3 \mathrm{E}-17$ & 0.34 & 107.87 \\
\hline & $5 \times 5$ & 6.7 & 1.74 & 0.73 & 0.96 & 1.89 & 0.53 & -12.97 \\
\hline & $7 \times 7$ & 11.9 & 1.39 & 0.63 & 0.83 & 5.64 & 0.71 & -15.16 \\
\hline & $9 \times 9$ & 19.3 & 1 & 0.47 & 0.62 & -1.03 & 0.85 & 10.86 \\
\hline & $15 \times 15$ & 22 & 1 & 0.21 & 0.28 & 3.46 & 0.95 & -5.38 \\
\hline \multirow{5}{*}{ 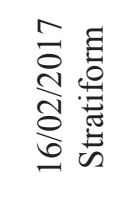 } & $3 \times 3$ & 17 & 2.1 & 0.46 & 1.34 & 1.70 & 0.77 & -0.90 \\
\hline & $5 \times 5$ & 18 & 1.8 & 0.21 & 0.63 & 2.72 & 0.94 & 3.32 \\
\hline & $7 \times 7$ & 24 & 1.8 & 0.06 & 0.18 & 2.99 & 1.00 & -8.53 \\
\hline & $9 \times 9$ & 16 & 1 & 0.10 & 0.29 & -2.71 & 0.98 & -1.45 \\
\hline & $15 \times 15$ & 66 & 0.8 & 0.03 & 0.09 & -2.93 & 1.00 & 1.11 \\
\hline \multirow{5}{*}{ 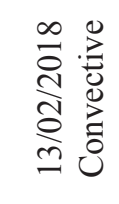 } & $3 \times 3$ & 179 & 1.2 & 0.38 & 1.27 & 8.31 & 0.84 & -1.63 \\
\hline & $5 \times 5$ & 199 & 1.4 & 0.49 & 1.64 & -3.74 & 0.74 & 26.16 \\
\hline & $7 \times 7$ & 192 & 1.1 & 0.06 & 0.21 & -3.03 & 1.00 & -31.89 \\
\hline & $9 \times 9$ & 280 & 1 & 0.04 & 0.14 & -1.39 & 0.99 & 1.17 \\
\hline & $15 \times 15$ & 197 & 1.1 & 0.02 & 0.08 & 2.69 & 1.00 & -0.33 \\
\hline \multirow{5}{*}{ 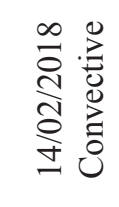 } & $3 \times 3$ & 7 & 1.3 & 0.64 & 2.84 & -1.33 & 0.57 & 18.58 \\
\hline & $5 \times 5$ & 18 & 1 & 0.29 & 1.32 & 0 & 0.90 & 7.92 \\
\hline & $7 \times 7$ & 15 & 1 & 0.18 & 0.79 & 1.66 & 0.97 & -78.64 \\
\hline & $9 \times 9$ & 15 & 1 & 0.09 & 0.40 & -5.41 & 0.99 & 0.08 \\
\hline & $15 \times 15$ & 20 & 0.6 & 0.04 & 0.19 & -5.02 & 1.00 & -0.38 \\
\hline \multirow{5}{*}{ 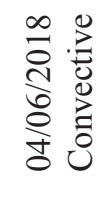 } & $3 \times 3$ & 6 & 2.7 & 0.70 & 2.83 & 8.52 & 0.46 & -3.77 \\
\hline & $5 \times 5$ & 13 & 2.4 & 0.62 & 2.52 & -1.54 & 0.57 & 5.50 \\
\hline & $7 \times 7$ & 166 & 1.5 & 0.57 & 2.29 & -7.97 & 0.65 & -22.18 \\
\hline & $9 \times 9$ & 265 & 1 & 0.38 & 1.53 & 1.19 & 0.85 & 1.24 \\
\hline & $15 \times 15$ & 92 & 0.9 & 0.01 & 0.06 & -1.61 & 0.99 & -0.60 \\
\hline
\end{tabular}

RSR: root mean square standard deviation ratio; RMSE: root mean square error; ME: mean error; PDCA: percentage difference in cumulative average precipitation.

Figure $6 \mathrm{c}, \mathrm{d}$. These results also contrast with others because for all models the results are far from the $\mathrm{r}=0.9$ correlation and 1 standard deviation.

Table VI summarizes all the calculated performance metrics to assess the differences between storm events. Except for the 20/07/2016 event, RSRs were smaller than 0.5 , indicating a satisfactory model at least at windows above $3 \times 3 \mathrm{~km}^{2}$, while the RSR of 0.6 is not reached for this event until the $15 \times 15 \mathrm{~km}^{2}$ window. On the other hand, the highest RMSE values resulted for the 20/07/2016 and 04/06/2018 convective storms, which occurred during the summer. 

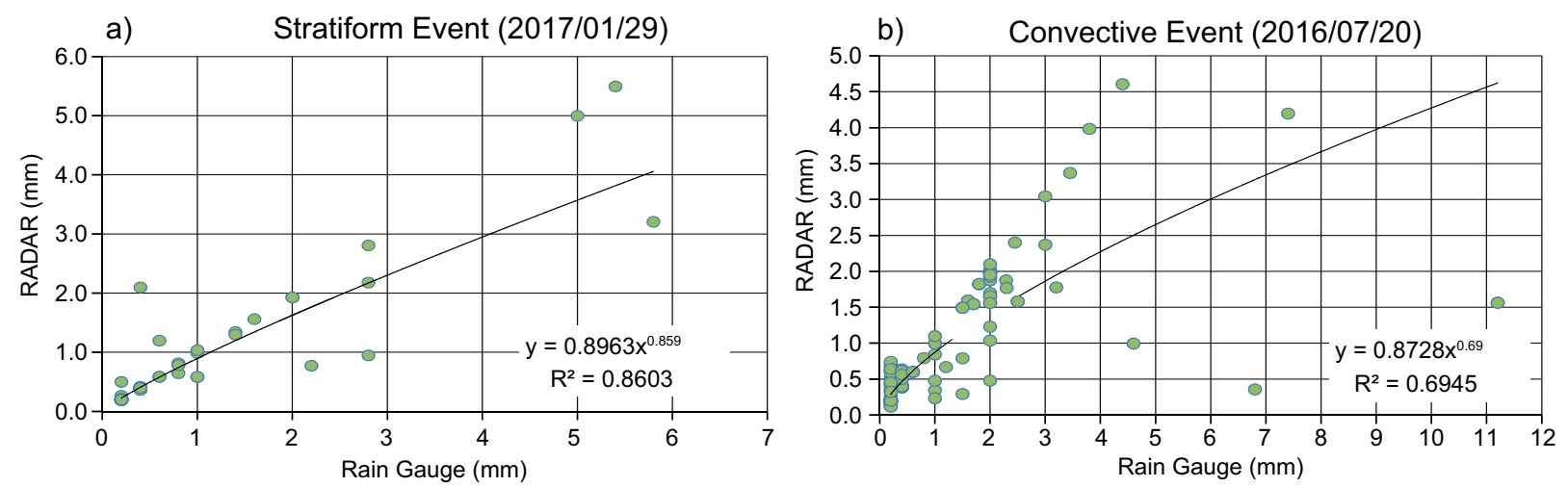

Fig. 7. Scatter diagrams of Rz-Rg values ( $\mathrm{mm}$ ), for (a) stratiform and (b) convective storm events.

$$
\text { 2016-02-01 }
$$

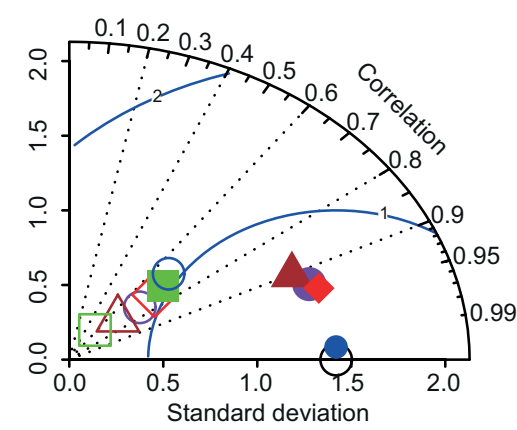

2017-02-16

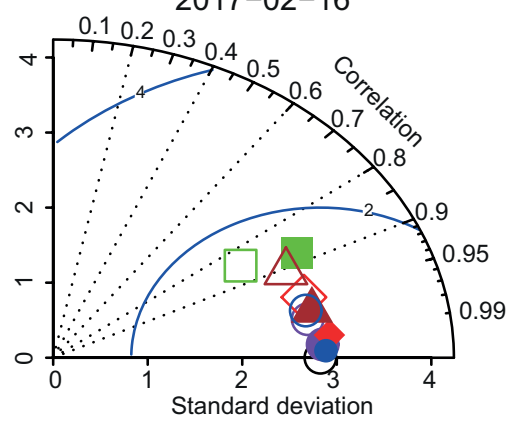

2018-02-13

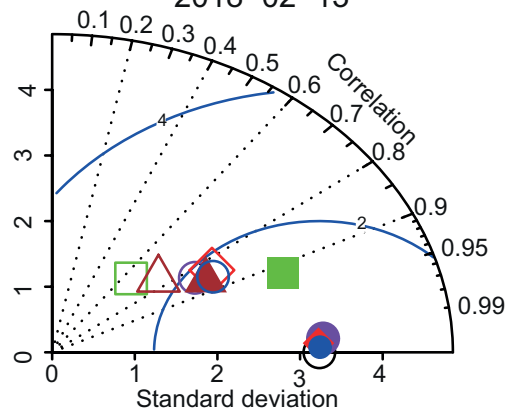

2016-07-20
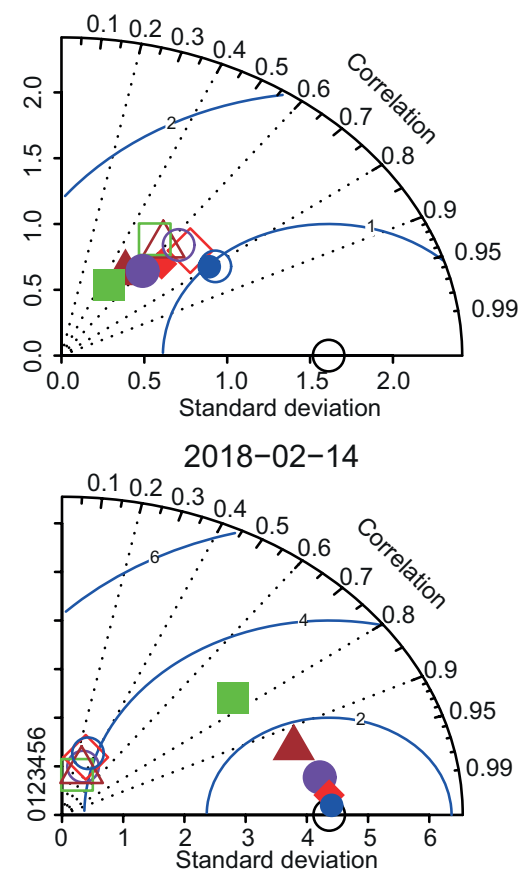

2017-01-29
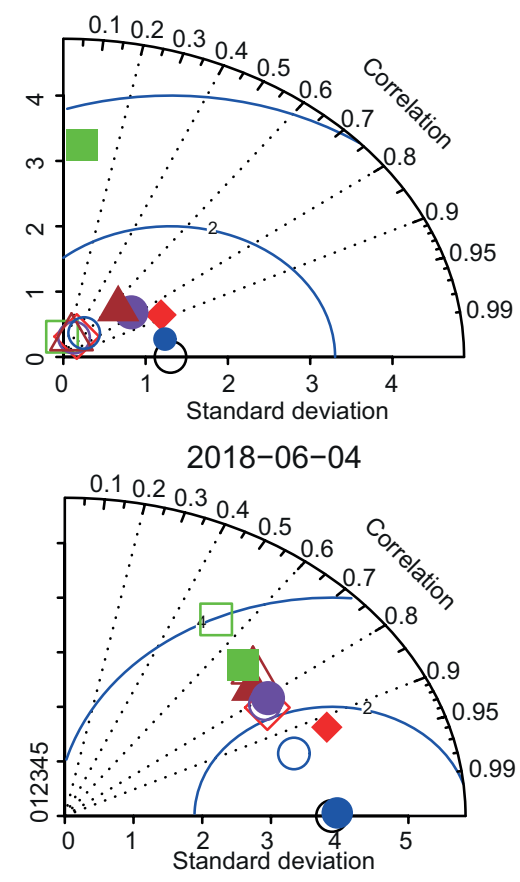

Fig. 8. Taylor diagrams for different space windows from $3 \times 3$ to $15 \times 15 \mathrm{~km}^{2}$ at time zero for all storm events. The hollow symbols indicate results (of SD and r) calculated using the Marshall and Palmer default model (MP), while the filled symbols indicate results using the optimization approach (OP) model. Observed (Rg) values are represented with the black circle. 
Similarly, the 20/07/2016 event had the highest ME values for all windows, while the lower ME values were reached at larger space windows. The same event had the worst $r^{2}$ values, where a medium correlation of $\mathrm{r}^{2}=0.64$ was reached until the $15 \times$ $15 \mathrm{~km}^{2}$ window; conversely, for the $16 / 02 / 2017$, $13 / 02 / 2018$, and $14 / 02 / 2018$ storms a perfect correlation was obtained at the $7 \times 7 \mathrm{~km}^{2}$ window. The last two events were convective, suggesting that the optimization method works better for this kind of storm. PDCA values were higher for the 20/07/2016 and 29/01/2017 events, for the best case $\left(15 \times 15 \mathrm{~km}^{2}\right.$ window); for the rest of the events, this value was below $1.1 \%$ for the same window. In summary, the worst error metrics were obtained for the 20/07/2016 event due to the presence of a few peak values or outliers, suggesting that the optimization works better with smooth data.

\section{Conclusions}

A new procedure for weather radar calibration was developed in this study and applied locally to optimize the power-law $\left(\mathrm{Z}=\mathrm{AR}^{\mathrm{b}}\right)$ in convective and stratiform storms. The resulting radar estimates using the optimized model were compared to the default Marshall and Palmer model, raindrop free fall. The method was tested in the lower Grijalva River basin in Mexico, which is prone to flood due to the abundance of rivers and high rainfall, for which reliable precipitation data is essential.

The optimal A and b parameters were larger for most of the convective storms (except for the $14 / 02 / 2018$ event) than for stratiform storms. This may be due to the magnitude of radar $Z$ values, which depend on raindrop size and are larger for convective storms (which exhibit large spatial variability). The same was also true for events where calibration data presented large peak values.

Just a few high peak values or outliers in the event 20/07/2016 decreased the performance of the optimization algorithm. Conversely, the results of estimates using the Marshall and Palmer model resulted in slightly better correspondence with observed data, because the calibration procedure is better in excluding those peak values. One possible reason for this is that MP parameters were calculated by averaging values from many storm events, so it makes sense that the estimates tend to converge to the mean, not accurately representing peak values.

In the WCMM method, the best $\mathrm{Z} / \mathrm{R}$ relation was found based on a user defined tolerance of the Pearson correlation coefficient (r). How good is the agreement between $\mathrm{Z}$ and the radar data depends on this tolerance value. The advantage of the proposed approach is that it guarantees maximum $\mathrm{Z} / \mathrm{R}$ relationship based directly on the maximization of the determination coefficient $\left(r^{2}\right)$ between the $Z / R$. This maximum relationship can be verified with the correlation curves ( $\mathrm{r}^{2}$ vs. parameters $\mathrm{A}$ or $\mathrm{b}$ ) provided by the method, and it is easy to identify which parameters are more convenient.

In window-based calibration methods it is important to establish some spatial range in which raindrops would fall due to horizontal wind advection. This justifies the selection of a maximum window dimension, considering important factors such as wind speed, time of raindrop fall, and the elevation error produced by the curvature of the Earth. The equations used in this work are good alternatives.

One limitation encountered in the study area is the scarce number of automatic rain gauges that can be used for calibration. This may affect the calibration by not detecting convective cores, so it is recommended to test the algorithm in areas with denser rain gauge networks. It is also important to note that data of the Sabancuy radar have significant uncertainties, even though it is one of the most modern in the country. In this work we corrected for the anomalous propagation and false echoes. However, the raw information could be improved further, correcting for the bright band, the VPR, attenuation, self-consistency, and calibrating reflectivity. Doing this before estimating the Z-R ratio could significantly improve the performance of the algorithm, particularly in convective events. The results indicate that the window-based algorithm developed in this study can be used in the local hydrological calibration of the radar installed at Sabancuy, and in other radars with similar characteristics. Furthermore, the estimates obtained using the optimized A and b parameters with the proposed algorithm constitute and improvement over the default Marshall and Palmer $\mathrm{Z} / \mathrm{R}$ relationship when applied to the LGRB. These new estimates could be used to enhance information produced by other data sources, as an input for hydrologic models to evaluate potential flood events in the LGRB. 


\section{Acknowledgments}

The authors thank the Servicio Meteorológico Nacional (SMN) of Mexico for providing the radar and rain gauge data and greatly appreciate the comments of two anonymous reviewers, which significantly improved the original manuscript. This work was conducted while the first author was a postdoctoral fellow at the Instituto de Geofísica, UNAM, supported by the Consejo Nacional de Ciencia y Tecnología (CONACyT).

\section{References}

Alfieri L, Claps P, Laio F. 2010. Time-dependent Z-R Relationships for estimating rainfall fields from radar measurements. Natural Hazards and Earth System Science 10: 149-158. https://doi.org/10.5194/nhess-10-149-2010 Ayat H, Reza Kavianpour M, Moazami S, Hong Y, Ghaemi E. 2018. Calibration of weather radar using region probability matching method (RPMM). Theoretical and Applied Climatology 134: 165-176. https://doi. org/10.1007/s00704-017-2266-7

Boushaki FI, Hsu K-L, Sorooshian S, Park G-H, Mahani S, Shi W. 2009. Bias adjustment of satellite precipitation estimation using ground-based measurement: A case study evaluation over the southwestern United States. Journal of Hydrometeorology 10: 1231-1242. https:// doi.org/10.1175/2009JHM1099.1

Brase CH, Brase CP, eds. 2009. Correlation and regression. In: Understandable statistics. Concepts and methods. 9th ed. Houghton and Miflin, New York, 509-529.

Calheiros RV, Zawadzki I. 1987. Reflectivity-rain rate relationships for radar hidrology in Brazil. Journal of Climate and Applied Meteorology 26: 118-132. https:// doi.org/10.1175/1520-0450(1987)026<0118:RRRR$\mathrm{FR}>2.0 . \mathrm{CO} ; 2$

Chai T, Draxler RR. 2014. Root mean square error ( RMSE ) or mean absolute error ( MAE)? - Arguments against avoiding RMSE in the literature. Geoscientific Model Development 7: 1247-1250. https://doi.org/10.5194/ gmd-7-1247-2014

Craciun C, Catrina O. 2016. An objective approach for comparing radar estimated and rain gauge measured precipitation. Meteorological Applications 23: 683690. https://doi.org/10.1002/met.1591

Ducrocq V, Ricard D, Lafore J-P, Orain F. 2002. Stormscale numerical rainfall prediction for five precipitating events over france: On the importance of the initial humidity field. Weather and Forecasting 17: 12361256. https://doi.org/10.1175/1520-0434(2002)017< 1236:ssnrpf $>2.0$. co; 2

Dufton DRL, Collier CG. 2015. Fuzzy logic filtering of radar reflectivity to remove non-meteorological echoes using dual polarization radar moments. Atmospheric Measurement Techniques 8: 3985-4000. https://doi. org/10.5194/amt-8-3985-2015

Gao J, Brewster K, Xue M. 2006. A comparison of the radar ray path equations and approximations for use in radar data assimilation. Advances in Atmosferic Sciences 23: 190-198. https://doi.org/10.1007/s00376-006-0190-3

Gou Y, Chen H, Zheng J. 2019. An improved self-consistent approach to attenuation correction for C-Band polarimetric radar measurements and its impact on quantitative precipitation estimation. Atmospheric Research 226: 32-48. https://doi.org/10.1016/j.atmosres.2019.03.006

Hakvoort HAM, Uijlenhoet R, Strieker JNM. 1993. Accuracy of radar rainfall estimates compared to raingauge measurements and a hydrological application currently at Water Authority West-Brabant. Available at: http://edepot.wur.nl/216654 (accessed on March 8, 2020).

Hill DJ, Baron J. 2015. radar.IRIS: A free, open and transparent $r$ library for processing Canada's weather radar data. Canadian Water Resources Journal 40: 409-422. https://doi.org/10.1080/07011784.2015.1074527

Hinojosa-Corona A, Rodríguez-Moreno VM, Munguía-Orozco L, Meillón-Menchaca O. 2011. El deslizamiento de ladera de noviembre 2007 y generación de una presa natural en el Río Grijalva, Chiapas, México. Boletin de La Sociedad Geologica Mexicana 63: 15-38. https://doi.org/ 10.18268/BSGM2011v63n1a2

Junker NW, Schneider RS, Fauver SL. 2002. A study of heavy rainfall events during the great midwest flood of 1993. Weather and Forecasting 14: 701-712. https://doi.org/10.1175/1520-0434(1999)014<0701 :asohre $>2.0$. co; 2

Lane J, Kasparis T, Jones L, Merceret F, Glito P, McFarquar G, Fisher B. 1998. Steps toward improved radar estimates of convective rainfall using spatial averages obtained from rain gauge clusters. In: Proceedings of the First International Conference on Geospatial Information in Agriculture and Forestry. Lake Buena Vista, Florida.

Li M, Shao Q. 2010. An improved statistical approach to merge satellite rainfall estimates and raingauge 
data. Journal of Hydrology 385: 51-64. https://doi. org/10.1016/j.jhydrol.2010.01.023

Long Y, Zhang Y, Ma Q. 2016. A merging framework for rainfall estimation at high spatiotemporal resolution for distributed hydrological modeling in a data-scarce area. Remote Sensing 8: 599. https://doi.org/10.3390/ rs8070599

Mantas VM, Liu Z, Caro C, Pereira AJSC. 2015. Validation of TRMM Multi-Satellite Precipitation Analysis (TMPA) products in the Peruvian Andes. Atmospheric Research 163: 132-145. https://doi.org/10.1016/j. atmosres.2014.11.012

Marshall JS, Palmer WM. 1948. The size distribution of raindrops. Journal of Atmospheric Sciences 5: 165-166. https://doi.org/10.1175/1520-0469(1948)005<0165:TDORWS $>2.0 . \mathrm{CO} ; 2$

Moriasi DN, Arnold JG, Liew MW Van, Bingner RL, Harmel RD, Veith TL. 2007. Model evaluation guidelines for systematic quantification of accuracy in watershed simulations. Transactions of the ASABE 50: 885-900. https://doi.org/10.13031/2013.23153

Morin E, Krajewski WF, Goodrich DC, Gao X, Sorooshian S. 2003. Estimating rainfall intensities from weather radar data: The scale-dependency problem. Journal of Hydrometeorology 4: 782-797. https://doi.org/10.1175 /1525-7541(2003)004<0782:erifwr >2.0.co;2

Nagelkerke NJD. 1991. A note on a general definition of the coefficient of determination. Biometrika 78: 691692. https://doi.org/10.2307/2337038

Newman MEJ. 2005. Power laws, Pareto distributions and Zipf's law. Contemporary Physics 46: 323-351. https:// doi.org/10.1080/00107510500052444

Pedrozo-Acuña A, Mariño-Tapia I, Enriquez C, Medellín Mayoral G, González Villareal FJ. 2012. Evaluation of inundation areas resulting from the diversion of an extreme discharge towards the sea: Case study in Tabasco, Mexico. Hydrological Processes 26: 687-704. https://doi.org/10.1002/hyp.8175

Piman T, Babel MS, Gupta A Das, Weesakul S. 2007. Development of a window correlation matching method for improved radar rainfall estimation. Hydrology and Earth System Sciences 11: 1361-1372. https://doi. org/10.5194/hess-11-1361-2007

Ramli S, Tahir W. 2013. Radar Hydrology: New Z/R Relationships for quantitative precipitation estimation in
Klang river basin, Malaysia. International Journal of Environmental Science and Development 2: 223-227. https://doi.org/10.7763/ijesd.2011.v2.128

Rico-Ramírez MA, Cluckie ID, Han D. 2005. Correction of the Bright Band Using Dual-Polarisation Radar. Atmospheric Science Letters 6: 40-46. https://doi. org/10.1002/asl.89

Rosenfeld D, Wolff DB, Amitai E. 1994. The window probability matching method for rainfall measurements with radar. Journal of Applied Meteorology 33: 682693. https://doi.org/10.1175/1520-0450(1994)033<06 82:twpmmf $>2.0 . c 0 ; 2$

Singh J, Knapp HV, Arnold JG, Demissie M. 2005. Hydrological modeling of the Iroquois river watershed using HSPF and SWAT. Journal of the American Water Resources Association 41: 343-360. https://doi. org/10.1111/j.1752-1688.2005.tb03740.x

Velasco-Martínez L, Mendoza-Palacios JD, Campos-Campos E, Castillo-Bolainas H. 2011. Analisis espacial de las lluvias en la subcuenca del bajo grijalva. In: 2do Congreso Nacional de Manejo de Cuencas Hidrográficas. Villahermosa, Tabasco, Mexico.

Venables WN, Smith DM, The R Core Team. 2019. An introduction to $\mathrm{R}$. Notes on R: A programming environment for data analysis and graphics. Version 3.6.1 (2019-07-05). Available at: https://cran.r-project.org/ doc/manuals/r-release/R-intro.pdf (accessed on March 8,2020 ).

Woldemeskel FM, Sivakumar B, Sharma A. 2013. Merging gauge and satellite rainfall with specification of associated uncertainty across Australia. Journal of Hydrology 499: 167-176. https://doi.org/10.1016/j. jhydrol.2013.06.039

Zavala Cruz J, Jiménez Ramírez R, Palma López D, Bautista F, Gavi Reyes F. 2016. Paisajes geomorfológicos: base para el levantamiento de suelos en Tabasco, México. Ecosistemas y Recursos Agropecuarios 3: 161-171. https://doi.org/10.19136/era.a3n8.643

Zhang S, Huang X, Min J, Zhang H. 2019. Improved fuzzy logic method to distinguish between meteorological and non-meteorological echoes using C-Band polarimetric radar data. Atmospheric Measurement Techniques Discussions:1-29. https://doi.org/10.5194/ amt-2019-337 